\title{
Article \\ Calcite-Mineralized Fossil Wood from Vancouver Island, British Columbia, Canada
}

\author{
George E. Mustoe ${ }^{1, *(D)}$ and Graham Beard ${ }^{2}$ \\ 1 Geology Department, Western Washington University, Bellingham, WA 98225, USA \\ 2 Vancouver Island Paleontology Museum, Qualicum Beach, BC V9K 1K7, Canada; gtbeard@shaw.ca \\ * Correspondence: mustoeg@wwu.edu
}

check for updates

Citation: Mustoe, G.E.; Beard, G. Calcite-Mineralized Fossil Wood from Vancouver Island, British Columbia, Canada. Geosciences 2021, 11, 38. https://doi.org/10.3390/geosciences 11020038

Received: 1 January 2021

Accepted: 16 January 2021

Published: 20 January 2021

Publisher's Note: MDPI stays neutral with regard to jurisdictional claims in published maps and institutional affiliations.

Copyright: (c) 2021 by the authors. Licensee MDPI, Basel, Switzerland. This article is an open access article distributed under the terms and conditions of the Creative Commons Attribution (CC BY) license (https:// creativecommons.org/licenses/by/ $4.0 /)$.

\begin{abstract}
Calcite-mineralized wood occurs in marine sedimentary rocks on Vancouver Island, British Columbia at sites that range in age from Early Cretaceous to Paleocene. These fossil woods commonly have excellent anatomical preservation that resulted from a permineralization process where calcite infiltrated buried wood under relatively gentle geochemical conditions. Wood specimens typically occur in calcareous concretions in feldspathic clastic sediment. Other concretions in the same outcrops that contain abundant mollusk and crustacea fossils are evidence that plant remains were fluvially transported into a marine basin. Fossiliferous concretions commonly show zoning, comprising an inner region of progressive precipitation where calcite cement developed as a concentric halo around the organic nucleus. An outer zone was produced by pervasive cementation, which was produced when calcite was simultaneously precipitated in pore spaces over the entire zone.
\end{abstract}

Keywords: calcite; concretions; fossil wood; paleobotany; permineralization; silicification; Vancouver Island

\section{Introduction}

Fossil wood occurs at many sites on Vancouver Island, (Figure 1), but these fossils have received scant attention from scientists. Early paleobotany work described leaf compression fossils preserved in shales and siltstones of the Nanaimo Group (Bell, 1957). Later, researchers have focused on permineralized plant remains, e.g., flowers, fruits, seeds, and cones. Much of this work has been done by paleobotanists R.A. Stockey and G.W. Rothwell and their students and colleagues e.g., [1-3]. The plethora of fossil plant organ studies is in sharp contrast to the paucity of work on mineralized woods. Taxonomic descriptions are limited to the angiosperm Paraphyllanthoxylon vancouverensis preserved as a $38 \mathrm{~cm}$ diameter log at the Eden Main locality [4] and the gymnosperm Cunninghamia hornbeyensis from Hornby Island [5]. Fossil palm logs have been reported from Hornby Island beds [6].

Our research is devoted to the mineralogy of the wood and the processes of fossilization. Regardless of age, fossil wood from Vancouver Island localities is mineralized with calcite. The mineralization of wood with calcium carbonate has previously been reported from 13 locations around the world, mostly in terrestrial deposits (Table 1). The occurrence of abundant calcite-mineralized wood preserved in shallow marine deposits on Vancouver Island, British Columbia is a notable addition to this list. 


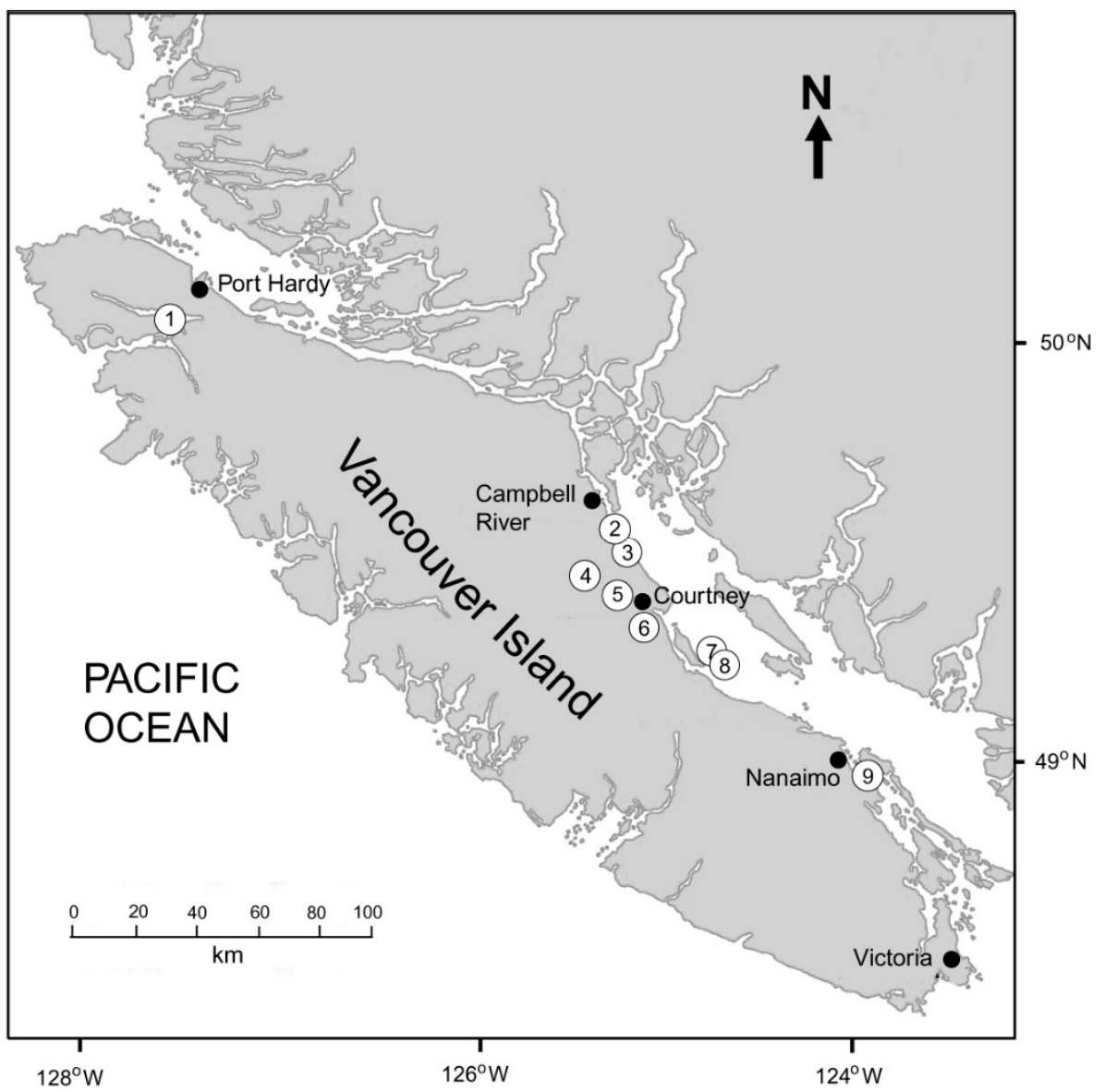

Figure 1. Vancouver Island plant fossil locations. (1). Apple Bay; (2). Shelter Point; (3). Appian Way; (4). Eden Main; (5). Puntledge River; (6). Trent River; (7). Denman Island; (8). Hornby Island; (9). Cranberry Arms.

Table 1. World-wide occurrences of woods mineralized with calcium carbonate.

\begin{tabular}{ccc}
\hline Location & Age & Reference \\
\hline Lucknow, Poland & Jurassic & {$[7]$} \\
Isle of Weight, England & Cretaceous & {$[8]$} \\
New Mexico, USA & Cretaceous & {$[9]$} \\
Kansas, USA & Cretaceous & {$[10]$} \\
Vancouver Island, Canada & Cretaceous, Paleocene & This report \\
Geiseltal, Germany & Eocene & {$[11]$} \\
Ellesmere Island, Arctic Canada & Eocene & {$[12]$} \\
Washington, USA & Miocene & {$[13]$} \\
Florida, USA & Neogene & {$[14]$} \\
Dunrobba, Italy & Pliocene & {$[15]$} \\
California, USA & Pleistocene & {$[16,17]$} \\
Ohio, USA & Pleistocene & {$[18,19]$} \\
Northern Ireland & Pleistocene & {$[20]$} \\
Weimar, Germany & Pleistocene & {$[21]$} \\
\hline
\end{tabular}

\section{Geologic Setting}

Fossil plant localities on Vancouver Island are found in the Upper Cretaceous Nanaimo Group and in adjacent Lower Cretaceous and Paleocene strata (Table 2). These formations comprise conformable beds and intergradational facies that record transitions from alluvial deposits to coastal, deltaic, and shallow marine basin sediments [22-24].

The paleogeographic origin of Vancouver Island sedimentary rocks remains unresolved. Namaimo Group sediments appear to have been deposited in a forearc basin 
where the strata were later subjected to thrust faulting and uplift (Figure 2). Perhaps these sediments were deposited at or near their present location. An alternate view is that the Nanaimo Group is part of an extensive assemblage of rocks that have been transported by high-angle faulting from a source area $\approx 3000 \mathrm{~km}$ to the south. This "Baja-BC" hypothesis, introduced in 1985 [25], is supported by shallow paleomagnetic inclination angles in sedimentary and volcanic rocks [26-28]. An intermediate interpretation is that northern transport was 1000-1600 km [29,30]. These divergent interpretations preclude the use of paleolatitude for paleoenvironmental reconstructions. Molluscan and crustacean fossils are locally abundant and provide evidence for estimating geologic age. These fossils typically occur in transgressive marine environments. Plant fossils in these beds are indicative of a warm temperate climate [31]; this paleoclimate does not solve the paleolatitude conundrum because mild temperatures were globally widespread during the Cretaceous and early Tertiary.

Table 2. Vancouver Island plant fossil localities. Data from $[23,32]$.

\begin{tabular}{|c|c|c|c|c|c|}
\hline \multicolumn{6}{|c|}{ North Vancouver Island } \\
\hline \multicolumn{2}{|c|}{ Formation } & Fossil Locality & Lithologies & $\begin{array}{l}\text { Depositional } \\
\text { Environment }\end{array}$ & Age \\
\hline \multicolumn{2}{|c|}{ Unnamed strata } & Port Hardy & sandstone & shallow marine & $\begin{array}{l}\text { Campanian } \\
\text { 72-94 Ma }\end{array}$ \\
\hline \multicolumn{2}{|c|}{ Longarm equivalent } & Apple Bay & sandstone & Shallow marine & $\begin{array}{c}\text { Valengian-Barremian } \\
140 \mathrm{Ma}\end{array}$ \\
\hline \multicolumn{6}{|c|}{ South Vancouver Island } \\
\hline \multicolumn{2}{|c|}{ Oyster Bay } & Oyster Bay & sandstone & Shallow marine & $\begin{array}{l}\text { Paleocene } \\
60 \mathrm{Ma}\end{array}$ \\
\hline \multicolumn{6}{|c|}{ unconformity } \\
\hline \multirow{11}{*}{ Nanaimo Group } & Gabriola & & sandstone & $\begin{array}{l}\text { submarine fan, high } \\
\text { energy }\end{array}$ & \multirow{2}{*}{$\begin{array}{l}\text { Maastrichtian } \\
66-72 \mathrm{Ma}\end{array}$} \\
\hline & Spray & Shelter Point & siltstone \& mudstone & $\begin{array}{l}\text { submarine fan, low } \\
\text { energy }\end{array}$ & \\
\hline & Geoffrey & & $\begin{array}{l}\text { conglomerate \& } \\
\text { sandstone }\end{array}$ & $\begin{array}{l}\text { submarine fan, high } \\
\text { energy }\end{array}$ & \multirow[t]{4}{*}{$\begin{array}{l}\text { Campanian- } \\
\text { Maastrichtian }\end{array}$} \\
\hline & Northumberland & Hornby Island & siltstone \& mudstone & $\begin{array}{l}\text { submarine fan, low } \\
\text { energy }\end{array}$ & \\
\hline & De Courcy & & $\begin{array}{l}\text { conglomerate \& } \\
\text { sandstone }\end{array}$ & $\begin{array}{l}\text { submarine fan, High } \\
\text { energy }\end{array}$ & \\
\hline & Cedar District & $\begin{array}{l}\text { Cranberry } \\
\text { Arms }\end{array}$ & siltstone \& mudstone & $\begin{array}{l}\text { submarine fan, low } \\
\text { energy }\end{array}$ & \\
\hline & Protection & & $\begin{array}{l}\text { sandstone, minor } \\
\text { conglomerate and } \\
\text { siltstone }\end{array}$ & $\begin{array}{l}\text { shallow marine to } \\
\text { deep submarine fan }\end{array}$ & \multirow[t]{2}{*}{$\begin{array}{l}\text { Campanian } \\
72-84 \mathrm{Ma}\end{array}$} \\
\hline & Pender & & siltstone, mudstone & $\begin{array}{l}\text { marine outer shelf } \\
\text { and slope }\end{array}$ & \\
\hline & Extension & & $\begin{array}{l}\text { conglomerate, minor } \\
\text { sandstone and coal }\end{array}$ & $\begin{array}{c}\text { nearshore marine } \\
\text { and } \\
\text { onshore deltaic and } \\
\text { fluvial }\end{array}$ & $\begin{array}{l}\text { Santonian- } \\
\text { Campanian }\end{array}$ \\
\hline & Haslam & & siltstone \& mudstone & $\begin{array}{l}\text { marine outer shelf } \\
\text { and slope }\end{array}$ & \multirow[b]{2}{*}{$\begin{array}{l}\text { Santonian } \\
84-86 \mathrm{Ma}\end{array}$} \\
\hline & Comox & Puntledge River & $\begin{array}{c}\text { conglomerate, } \\
\text { sandstone, mudstone, } \\
\text { coal }\end{array}$ & $\begin{array}{l}\text { nearshore marine } \\
\text { and fluvial }\end{array}$ & \\
\hline \multicolumn{2}{|c|}{ Unnamed strata } & Eden Main & Sandstone, mudstone & nearshore marine & $\begin{array}{c}\text { Turonian-Coniacian } \\
90 \mathrm{MA}\end{array}$ \\
\hline
\end{tabular}




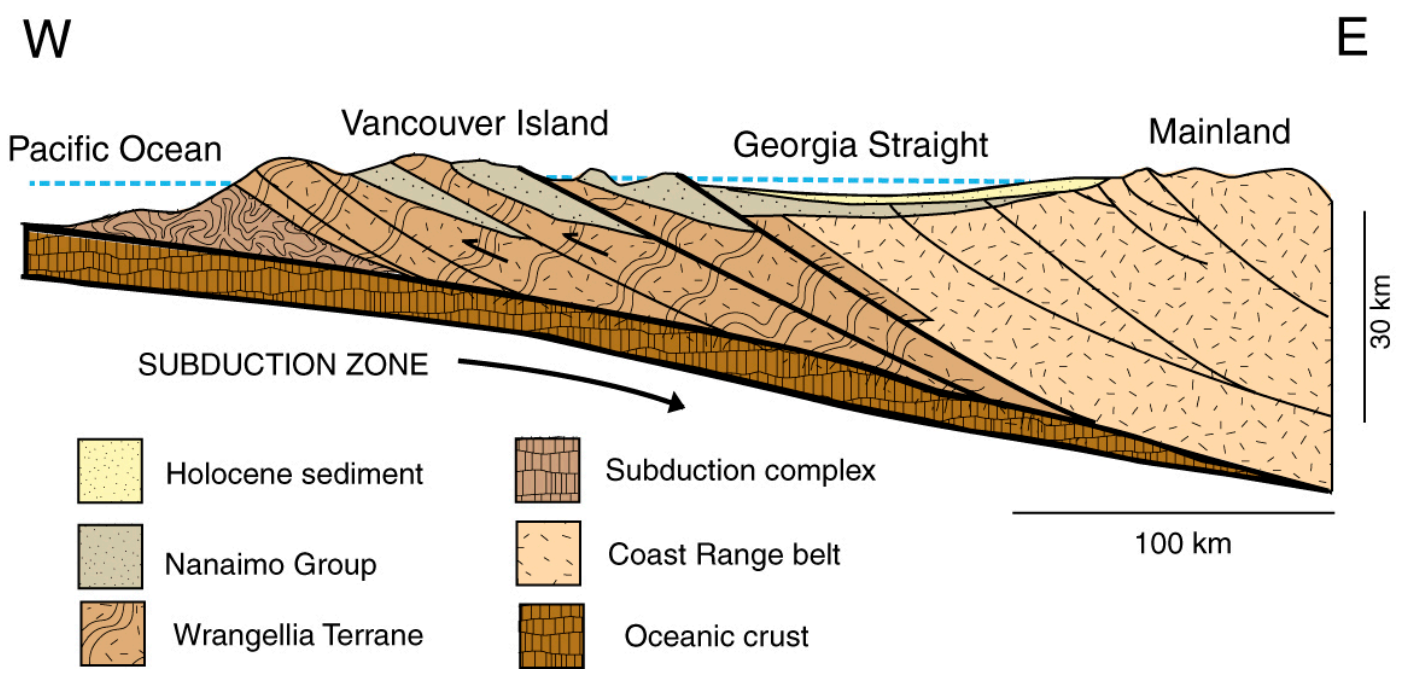

Figure 2. Generalized geological structure of the Upper Cretaceous Nanaimo Group. Adapted from [23].

\section{Materials and Methods}

Specimens used in this study come from the major Vancouver Island localities. Acetate peels of Apple Bay specimens were prepared by etching cut surfaces with $5 \% \mathrm{HCl}$. Petrographic thin sections were made at Western Washington University and photographed using a Zeiss petrographic microscope equipped with a 5 megapixel digital camera. SEM images are from a Tescan Vega scanning electron microscope. EDS spectra were obtained with an EDAX detector running Genesis software. SEM specimens consisted of rock fragments attached to $1 \mathrm{~cm}$ diameter aluminum stubs using epoxy adhesive. Samples were sputter coated with Pd to provide electrical conductivity. Fossil specimens, thin sections, and SEM specimens are archived in G.M.'s research collection at the Geology Department, Western Washington University.

\section{Results}

As mentioned, fossil wood specimens at all localities are mineralized with calcite, preserving varying amounts of relict organic matter. Large pieces have been found, including driftwood logs, but small fragments are more abundant (Figure 3). Fossil wood is commonly preserved as nuclei in calcareous concretions (Figure 4).

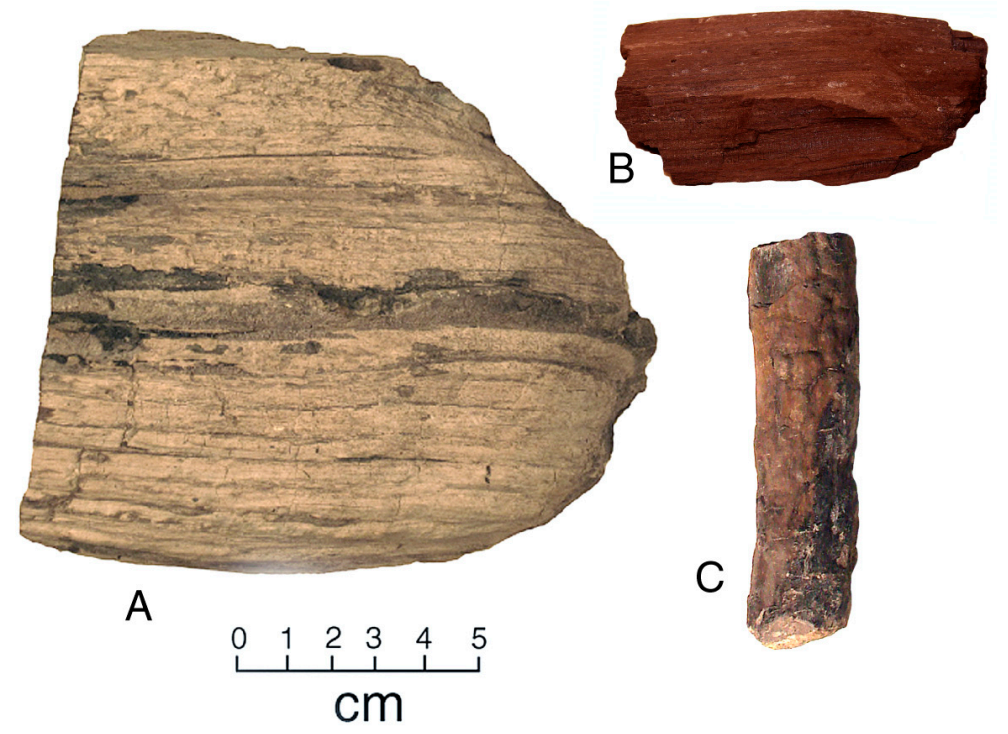

Figure 3. Fossil wood from Nanaimo Group strata. (A) Puntledge River. (B) Shelter Point. (C) Denman Island. 


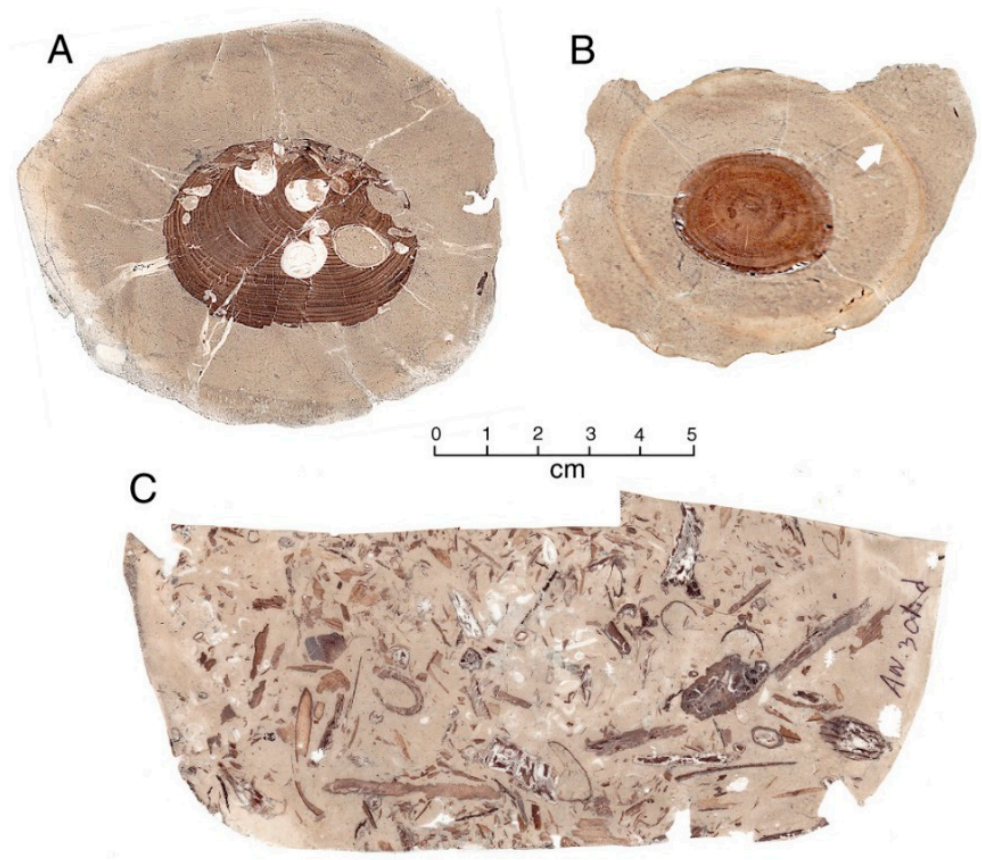

Figure 4. Acetate peels from Lower Cretaceous calcareous concretions from Apple Bay. (A) Transverse view of wood containing teredo borings. (B) Transverse view of limb, showing concentric zonation of concretionary matrix (arrow). (C) Concretion containing fragmental plant remains.

The preservation of relict tissue is evidenced by the cellular anatomy visible in acetate peels made from specimen surfaces that have been etched with $\mathrm{HCl}$ (Figures 4 and 5F). Although acetate peels have been widely used by paleobotanists [4], these peals do not provide information about mineralogy. Petrographic thin sections viewed under polarized transmitted light reveal the mineral composition (Figure 5).

Scanning Electron Microscope secondary electron images (Figure 6) show anatomical and mineralogic characteristics of fossil woods that have three-dimensional preservation, e.g., intercellular spaces, lumen, or vessels that are not fully mineralized. SEM/EDS spectra show calcium carbonate is the only major mineral constituent (Figure 7). For silicified wood, the magnitude of the $C$ peak is an indication of the abundance of relict organic matter. For calcite mineralized wood, the carbonate composition always produces a large $C$ peak in $X$-ray fluorescence spectra. If $C$ and $C$ a could both be measured accurately, the $\mathrm{C}:$ Ca atomic ratio would be $1: 1$, with a mass ratio of 0.32 . As a result of its very low $\mathrm{X}$-ray energy $(0.277 \mathrm{KeV}), \mathrm{C}$ abundance cannot be accurately quantified in EDS spectra. However, some clues to the presence of relict organic are offered by the height ratio of C:Ca peaks. In calcite mineralized wood, the height of the $C$ peak is elevated when organic compounds are present, representing $\mathrm{C}$ in excess of the amount required to produce $\mathrm{CaCO}_{3}$. Apple Bay and Puntledge River specimens have C:Ca peak height ratios of 0.82 and 0.78 , respectively. These ratios are inferred to represent elevated $C$ levels based on the observation that these fossil woods yield anatomically detailed acetate peals. The C:Ca ratio of 3.2 for the Port Hardy wood is evidence of a much higher percentage of relict organic matter than the Apple Bay and Puntledge River fossil woods. 


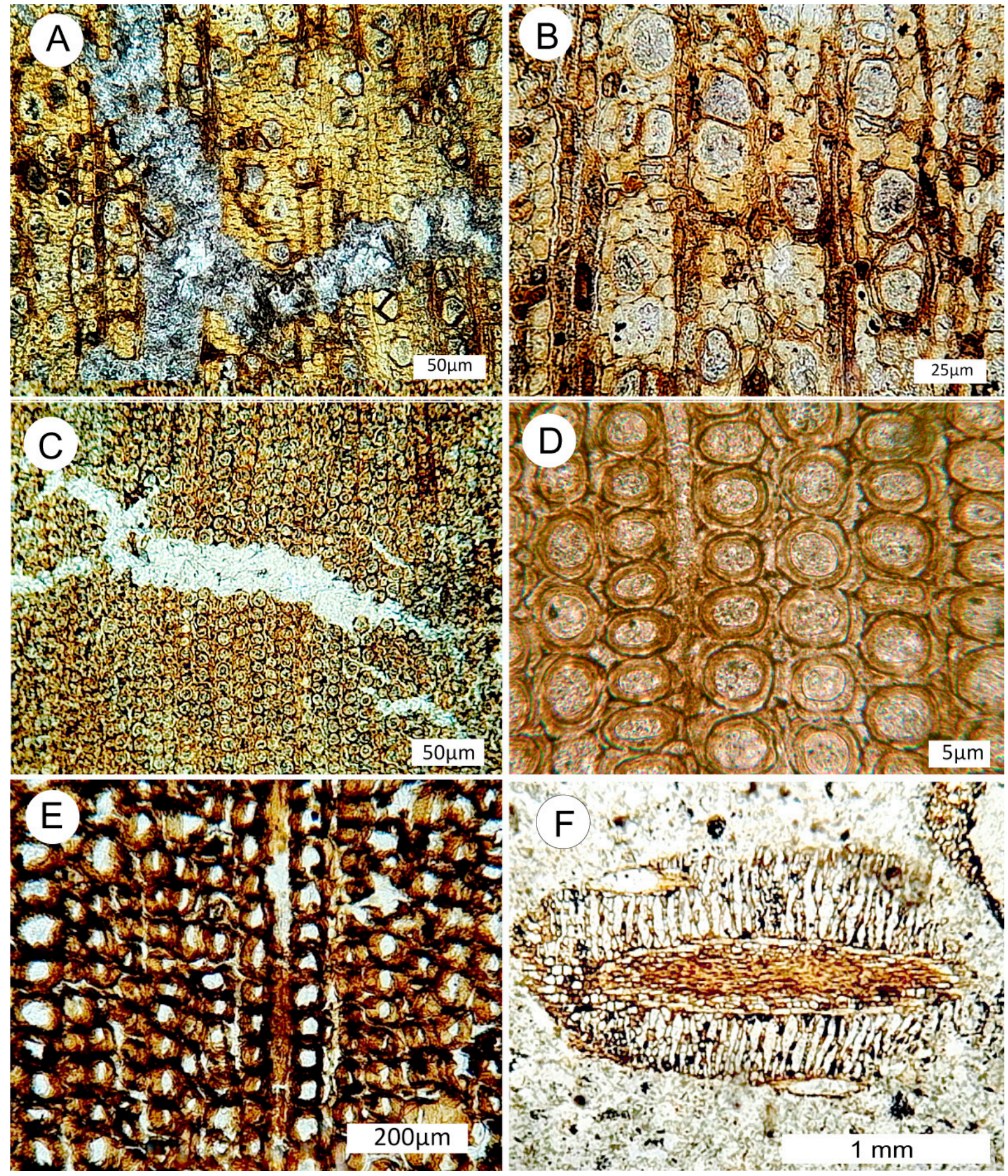

Figure 5. Optical photomicrographs of Nanaimo Island calcite-mineralized wood. (A,B) Thin section views of Upper Cretaceous wood from Collishaw Point, Hornby Island. (A) Transverse view showing prominent calcite vein. (B) Transverse view showing brown cell walls and lighter colored lumen. (C,D) Thin section views of Upper Cretaceous conifer wood from Puntledge River locality. (C) Transverse view showing calcite vein. (D) Transverse view showing thick cell walls and calcite-filled lumen. (E,F) Acetate peels of Lower Cretaceous conifer wood from Apple Bay. (E) Transverse view showing cell walls preserving relict organic matter. (F) Oblique transverse view of conifer leaf, showing central vascular bundle surrounded by mesophyll cells. 


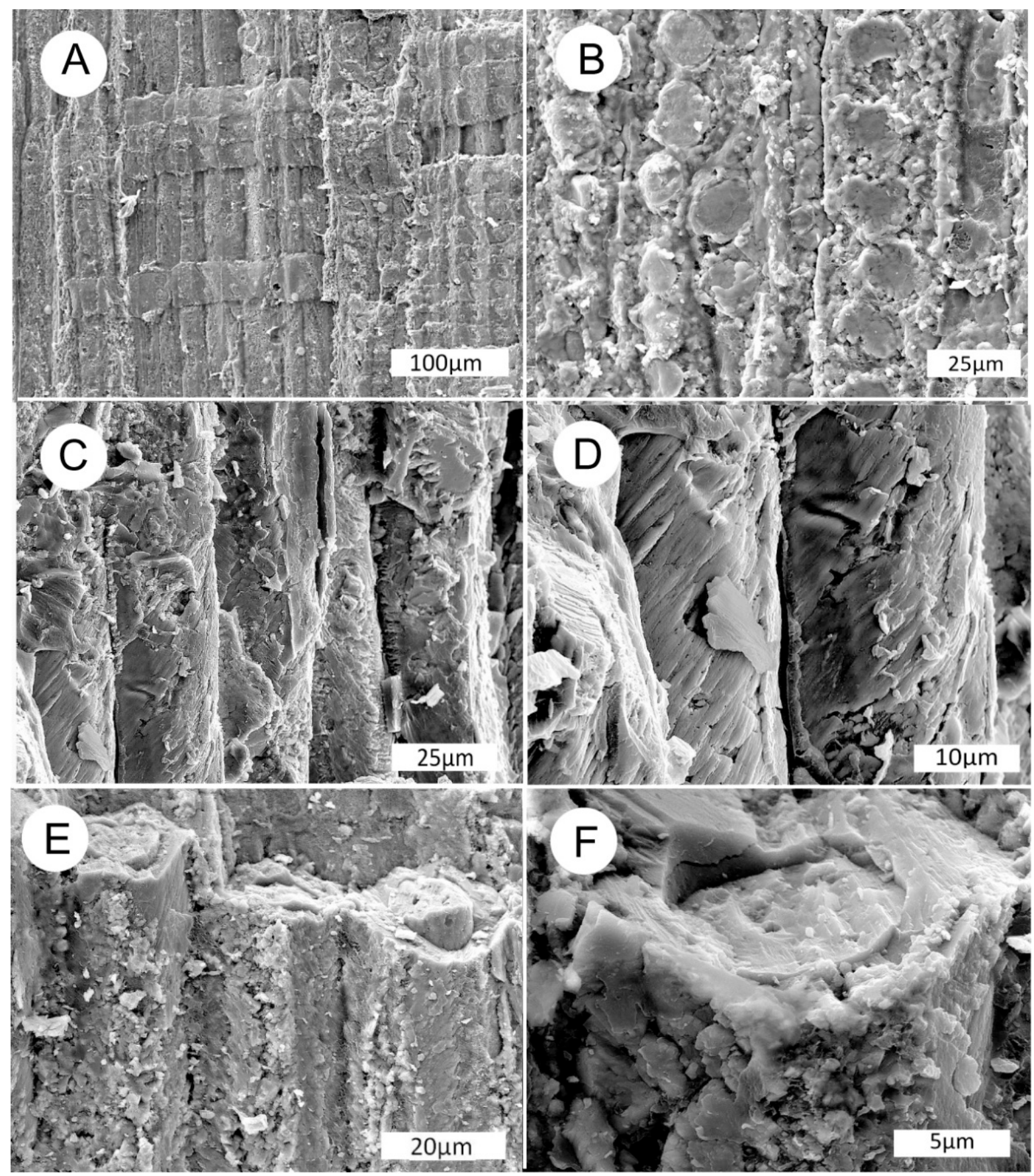

Figure 6. SEM images of calcite-mineralized wood. (A) Apple Bay wood (Lower Cretaceous) showing vertical tracheids and horizontal ray cells. (B) Apple Bay wood, radial view showing mineralized casts of circular intervessel pits. (C) Port Hardy wood (Upper Cretaceous), tracheid cells in radial view. (D) Port Hardy wood, showing mineralized cell walls. (E) Puntledge River wood (Upper Cretaceous), oblique radial view. (F) Puntledge River wood, oblique view of a tracheid with calcite permineralized cell walls, and lumina filled with crystalline calcite. 


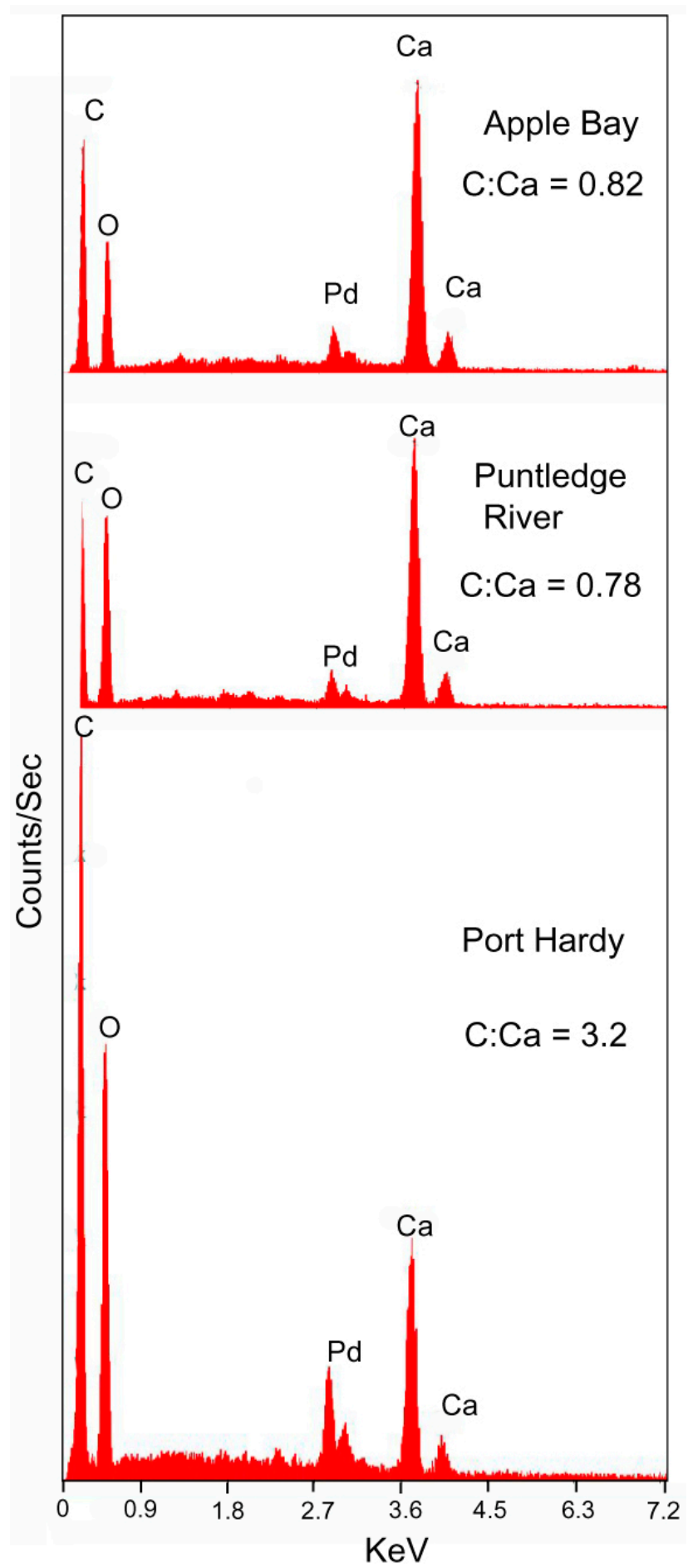

Figure 7. Energy dispersive X-ray fluorescence spectra. Pd peak is from coating applied to provide electrical conductivity. C:Ca peak height ratios provide an approximate indication of the abundance of relict organic matter.

\section{Discussion}

The process of calcite mineralization of ancient wood has received scant attention. Of the occurrences listed in Table 2, only three investigators considered fossilization processes. Sweeny et al. [9] described late Cretaceous wood preserved in fine sediments deposited along a low elevation floodplain in New Mexico, USA. Most fossil woods are silicified, but some specimens are mineralized with calcium phosphate, and charcoalified wood is also 
present. Calcite occurs cell fillings in fragments of charcoal and presumably represents a late stage of mineralization.

At Ellesmere Island, Arctic Canada, Eocene calcite-mineralized stumps are associated with coal seams that occur within sandstone and siltstone deposited on a low-elevation delta plain [12].

Higgins [16,17] reported one of the only known marine occurrences of calcite mineralized wood, from late Cretaceous deposits near Sacramento, California USA. The paleoenvironment appears to have been a nearshore basin with free circulation and strong local currents.

Fossil wood at Vancouver Island occurs in geologic depositional environments that are quite different from the above examples. These formations are predominately composed of clastic sediments that range in grain size from conglomerate to claystone. Leaf fossils in coal-bearing beds represent coastal lowland forests, but most other fossils were preserved in shallow marine basins. Skeletal remains of mosasaurs, elasmosaurs, icthyosaurs, plesiosaurs, and sea turtles represent pelagic vertebrates [33], and the Vancouver Island beds are world-famous for their preservation of ammonites and other marine invertebrates. The proximity to land is evidenced by the abundance of transported plant remains in these marine deposits. The accumulation of fine sediments suggests the absence of strong bottom currents. The absence of phosphate mineralization of the wood and the scarcity of invertebrate fossils were inferred to indicate that the sediments were deposited in a geosynclinal basin that was at least partially blocked off from the open sea. In contrast, wood-bearing beds on Vancouver Island contain abundant molluscan and crustacean fossils, often in the same strata that preserve fossil wood. Framboidal pyrite is a common minor constituent of fossil-bearing concretions.

\subsection{Fossilization Processes}

Permineralization occurs when wood tissue is entombed by minerals that precipitated after burial. Although relict organic compounds may preserve the anatomical form of the original tissue, the components of wood are likely to be quite different from the original forms [34]. One of the most important changes is the breakdown of cellulose. Lignin is a complex cross-linked polymer that is relatively resistant to degradation. As a result of its stability, lignin is likely to be a major contributor to relict carbon in fossil wood. For this reason, ancient woods are sometimes described as "lignified". As described below, mineralization involved localized geochemical gradients that were linked to the degradation of organic matter.

For animals, the breakdown of proteins typically results in a strong $\mathrm{pH}$ increase because amino acids and nucleic acids decompose to produce ammonia. For plant tissues, degradation involves different pathways. Although cytoplasm contains proteins and nucleic acids, wood largely consists of empty cells whose walls are composed of cellulose, hemicellulose, and lignin. These polymers are relatively stable, and fungi are the principle agent for their degradation. Cell wall degradation is accomplished by enzymatic reactions, where molecular linkages are cleaved, causing depolymerization [35]. Since cellulose and hemicellulose are polysaccharides, the end products of decomposition are simple sugars (e.g., glucose). Although these reactions do not produce the strong $\mathrm{pH}$ shifts that result from the degradation of nitrogenous compounds, the reaction products may serve as nutrients for microbes that may affect geochemical conditions. The common occurrence of framboidal pyrite suggests that bottom conditions were poorly oxygenated; microbial processes were presumably anaerobic.

The most visible evidence of wood degradation is the presence of holes carved by pelecypods of the Teredunidae Family, e.g., Teredo (Figure 4A). Although anatomical detail is well-preserved in many specimens, some concretions contain fossil wood that shows cellular disorganization caused by decay (Figure 8). In subaerial environments, wood decay is primarily caused by fungi, but in anaerobic marine environments, wood degradation is mainly related to bacteria [36]. The relatively slow rate of this degradation is consistent 
with observations of recent waterlogged wood. Wood-hulled shipwrecks have remained intact after several centuries of sea bottom exposure e.g., [37], and wood buried in Late Pleistocene deposits has ages $>100,000$ years BP $[38,39]$. Vancouver Island fossil woods commonly show excellent anatomical preservation, but after millions of years, this relict tissue is no longer pristine wood.

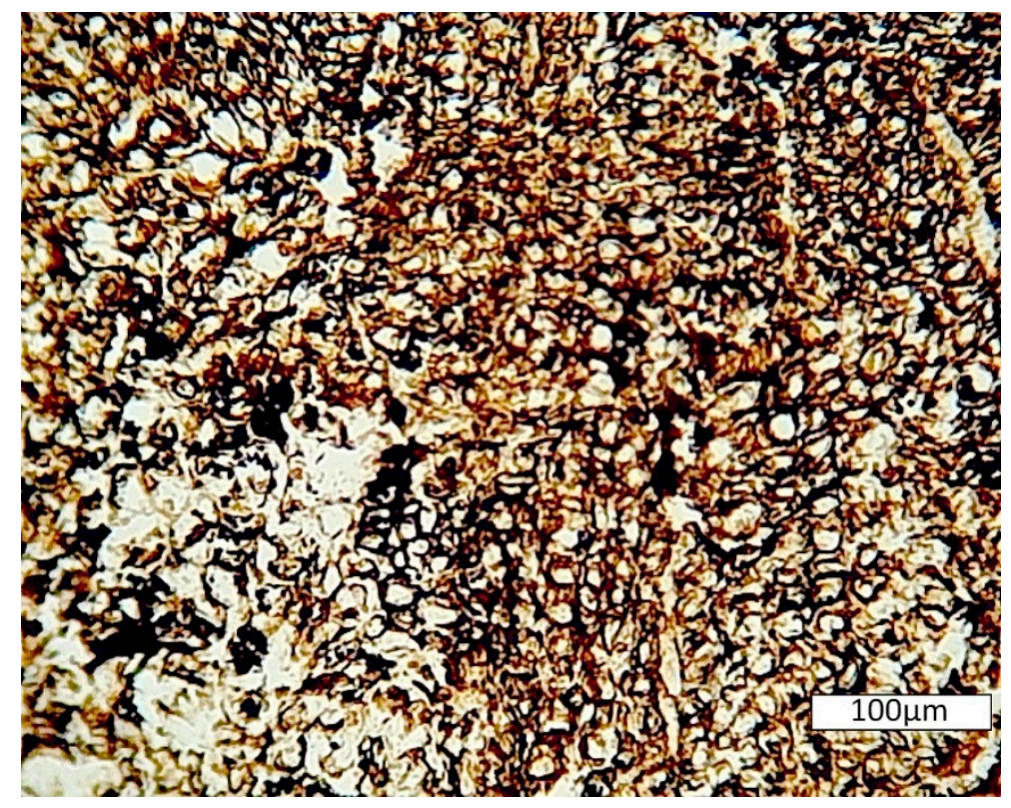

Figure 8. Partially decayed Lower Cretaceous conifer wood from Apple Bay.

\subsection{Calcite Mineralization}

In Vancouver Island fossil woods, relict cellular tissue is entombed within calcite precipitated from porewater. This process of permineralization has long been invoked to explain the preservation of woods preserved with silica, but recent research shows that most silicified woods have resulted from replacement, not permineralization [14]. Therefore, the recognition that Vancouver Island woods are preserved as true permineralizations is an important discovery.

Experimental studies show that the precipitation of silica and calcite occur under $\mathrm{pH}$ conditions that are largely mutually exclusive. At $\mathrm{pH}>8$, calcite is favored even when dissolved Si levels are high. Modern sea water $\mathrm{pH}$ levels locally range from 5.0 to 9.0, with an average of $\approx 8.1$ [40]. Oceanic $\mathrm{pH}$ values are largely controlled by atmospheric $\mathrm{CO}_{2}$ levels, which have varied over geologic time [41]. The acidity of sea water may have been very different during the Cretaceous (Figure 9). Elevated atmospheric $\mathrm{CO}_{2}$ results in elevated carbonic levels in seawater, which in turn increases the solubility of calcium carbonate minerals aragonite and calcite. Seawater acidification may have an adverse effect on marine life, including shellfish [42], but the bioavailability of calcium is evidenced in the Vancouver Island formations by the abundance of shelled invertebrate fossils. However, greater Cretaceous seawater acidity may explain why these strata do not include limestone deposits. The abundance of calcareous concretions in lithic sediments is evidence of localized geochemical environments that favored calcite precipitation. These zones are probably related to localized geochemical gradients caused by the decomposition of organic matter. 


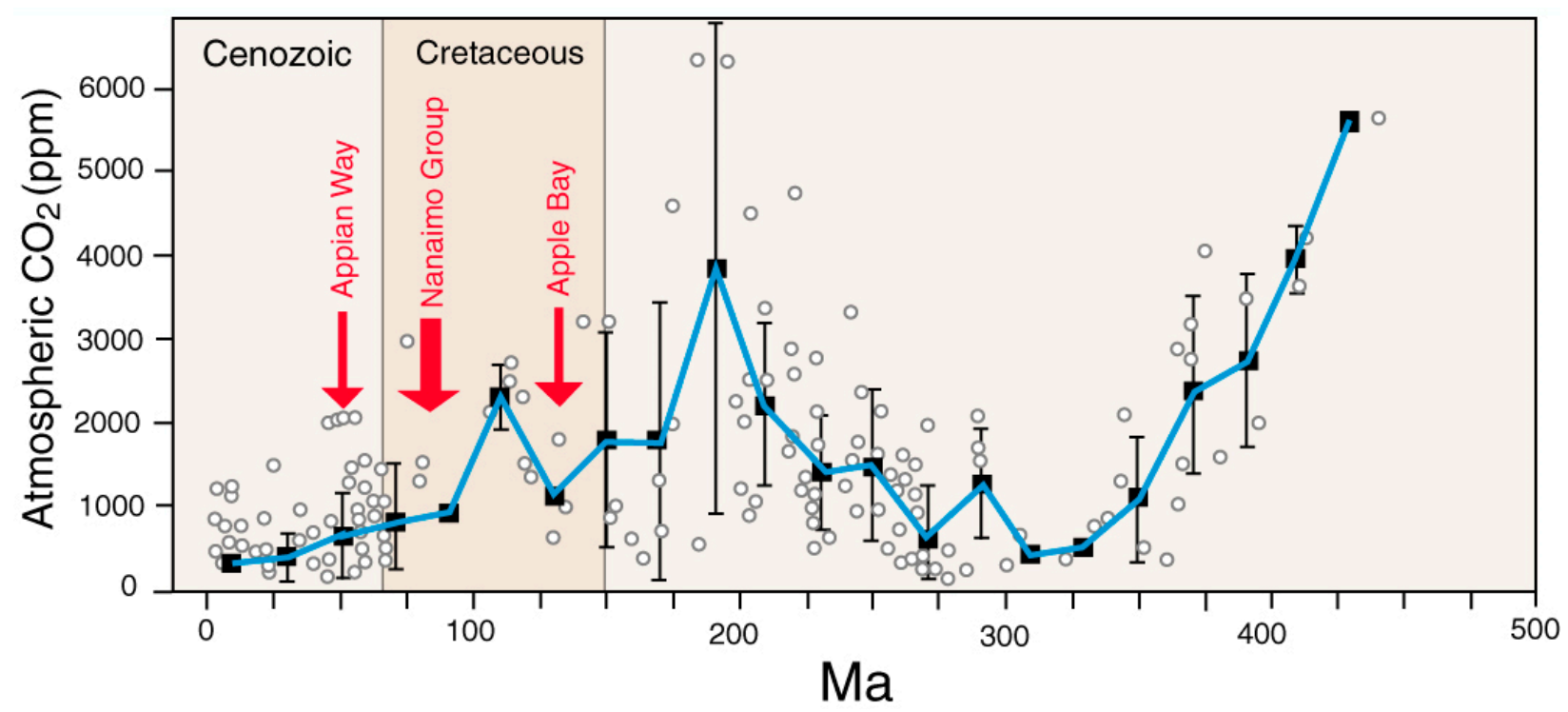

Figure 9. Atmospheric $\mathrm{CO}_{2}$ levels through deep time. Adapted from [41].

Woods mineralized with calcite result from very different fossilization processes compared to silicified woods. For silicified wood, the process of mineralization begins via "organic templating" when dissolved silicic acid molecules form hydrogen bonds with organic constituents of inner cell walls [43]. The cell anatomy acts as a template for these silica layers, so the incipient mineralization of cell walls is the first step in preserving anatomical detail. Later, silica may be deposited in open spaces: cell lumen, vessels and intercellular spaces. Therefore, silicification is a multi-phase process [44]. As water is lost, hydrous silica is converted to opal; subsequent diagenesis may convert early amorphous opal to opal-CT, chalcedony, or quartz. Silicification occurs concurrently with tissue degradation, and the degree of anatomical preservation is related to the respective rates of these processes. In most cases, silicified wood preserves only a small percentage of the original organic matter [45]. The colors of silicified woods are diverse and include many bright colors caused by trace metals [46].

The processes of calcium carbonate mineralization of wood are probably quite different. As with silicification, the absorption of mineral-bearing pore water is likely the first step, because the basic cellular structure of wood facilitates fluid transport. Calcite may initially precipitate within spaces in multilayered cell walls, but without the hydrogen bonding "organic templating" affinity that occurs with silicic acid. With calcite precipitation, much of the organic matter remains, with cell walls being entombed rather than replaced. Similar to silicification, calcite mineralization may be a multi-stage process, with cell lumina, vessels, and intercellular spaces becoming filled with crystalline calcite after the walls have been mineralized (Figure 6). Colors of calcite-mineralized wood lack the bright colors observed in many silicified woods. Calcite wood is commonly a shade of brown, the color being caused by relict organic matter, not metallic trace elements.

Calcite permineralizations commonly preserve excellent anatomical detail, but in rare instances, crystal growth can disrupt tissues. Figure 10 shows fossil wood that has been subject to the radial growth of calcite crystals that have torn apart the tissue. This phenomenon has been described as "fibrous displacive calcite" [47]. The expansive effects of calcite crystallization result from the force of crystallinity, which can reach pressure of 10 atmospheres-equivalent to overburden pressures at a burial depth of $41 \mathrm{~m}$ [47]. The nucleation of fibrous displacive calcite may occur at sites that contain abundant microbes that concentrate $\mathrm{Ca}$ at their cell walls [48]. Microbial degradation may be a factor in mineralization of the Port Hardy wood, where the tissue appears to have undergone extensive disintegration. The radiating calcite crystals commonly have a small wood fragment as a nucleus, with a thin zone of cells bordering the outer margin. 


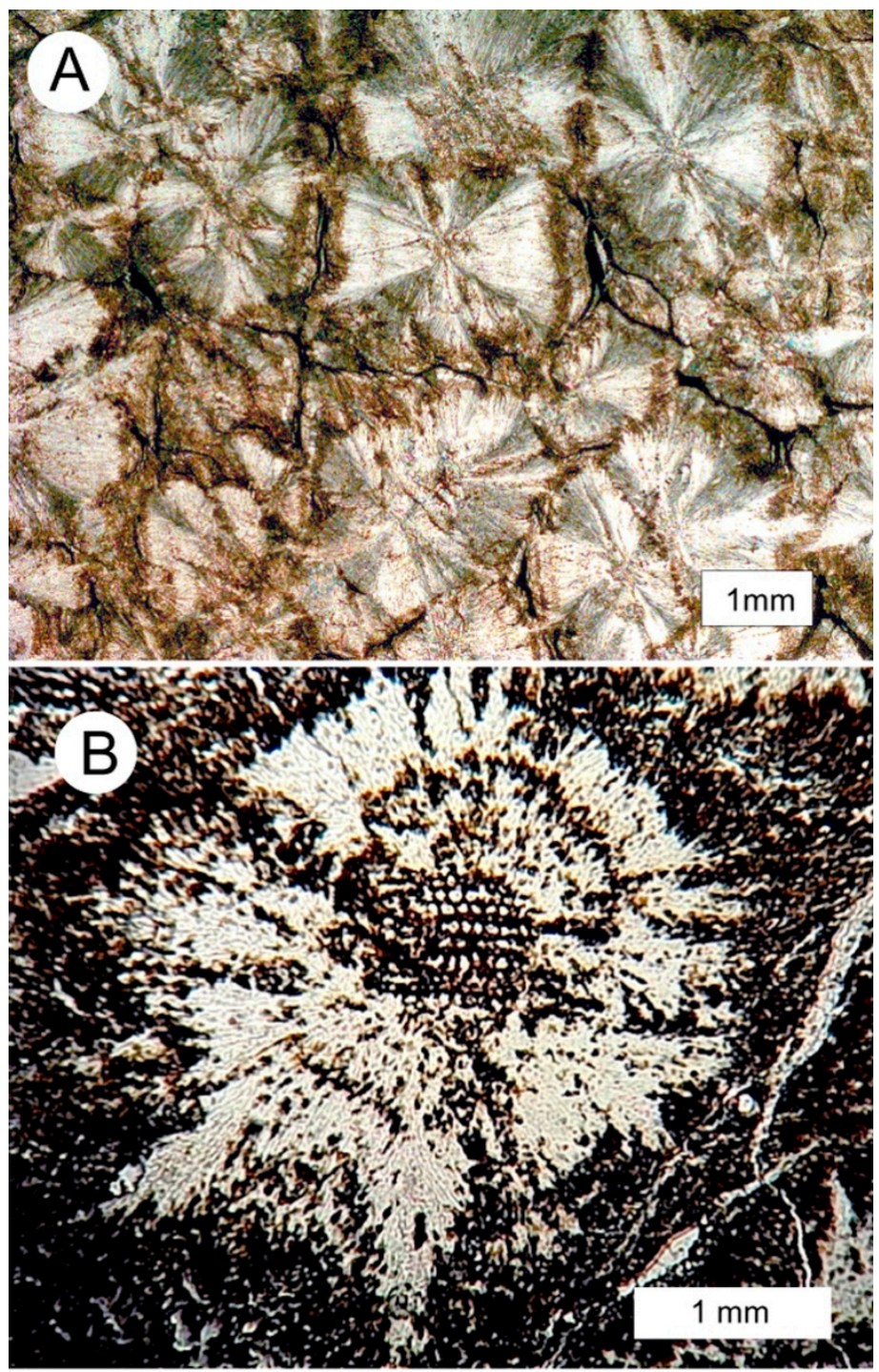

Figure 10. Fossil conifer wood from Port Hardy. (A) Thin section shows tissues to have a popcorn-like texture known as fibrous displacive calcite, where the growth of radiating calcite crystals produced severe anatomical distortion. (B) Acetate peel illustrates how small shards of cellular tissue commonly served as nuclei for the growth of radiating crystals.

\subsection{Formation of Calcareous Concretions}

Calcite-cemented concretions have worldwide occurrence, which is found in both terrestrial and marine environments. Diameters range in size from a few $\mathrm{cm}$ to several $\mathrm{m}$ (McBride et al., 2003). No single model explains all types of concretionary growth [49], but several generalizations can be made. Calcareous concretion formation has several physical and chemical requirements: a supply of dissolved calcium, permeability in the sediment, a nucleus for calcite crystallization, and environmental conditions that favor this precipitation. In sediment where permeability is the same in all directions, concretionary growth produces a spherical shape. Directional porewater flow produces elongate concretions.

Vancouver Island marine sediments contain several different concretion types. These include septarian concretions that contain a central region of mineral-filled fractures [50]. More common are large ovoid concretions that lack a central nucleus. In other regions, similar concretions have been suggested to have resulted from a chemical self-organization process [47]. A third type has attracted the attention of paleontologists. These concretions, which are abundant, contain plant or animal remains as a nucleus for calcite crystallization. The morphology of fossil has a strong influence on the shape of the concretion. 
Vancouver Island fossiliferous concretions are commonly zoned. They may have smooth exteriors, but weathered, broken, or sawn specimens reveal distinct concentric layers (Figure 11). The initial cementation presumably resulted from the precipitation of calcite cement as a halo around the buried wood. This type of concretion growth has been described as "concentric" [51]. The microenvironment where concentric growth occurs may have been mediated by sulfur-reducing bacteria that were nourished by degradation products of the original tissue, as evidenced by the common presence of pyrite framboids [52].

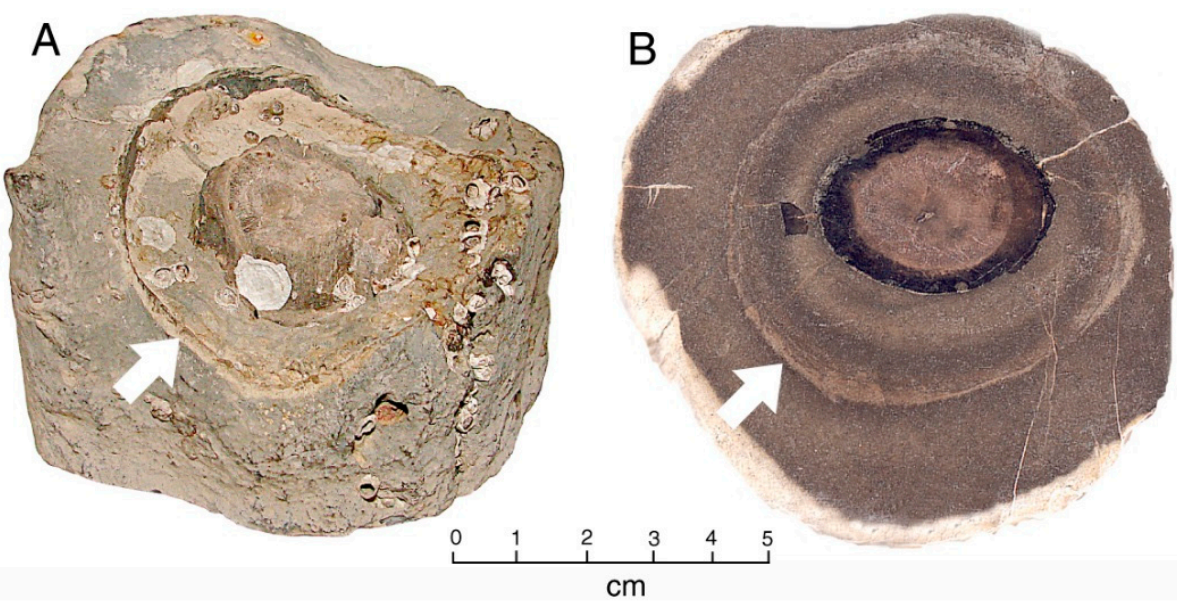

Figure 11. Transverse view of permineralized limb in calcareous concretion from intertidal zone at Collishaw Point, Hornby Island. (A) Exterior view of weathered concretion, showing whitish scars left by attached barnacles. (B) Polished sawn surface. Arrows mark the outer boundary of the concentric zone of calcification. The outer surfaces of the concretion are the boundary limit for the pervasive phase of cementation. Note that the concentric zone is partially bleached near the fossil wood. The darkest layer is carbon-rich bark.

Concretionary zones are inferred to have developed progressively $[47,53]$. The region closest to the fossil nucleus commonly shows bleaching (Figures 4B and 12B). In Vancouver Island fossiliferous concretions, the concretionary zone is commonly surrounded by an outer layer with a sharply defined contact. The inner zone may represent the region where calcite cement precipitated because of a geochemical gradient that was created by degradation of the organic nucleus. In this zone, carbon remobilization may be caused by sulfate-reducing bacteria that metabolize the original organic matter. The outer zone is believed to result from a process where calcite cement precipitates simultaneously rather than progressively. This process has been described as "pervasive growth". This zone has been suggested to result from methanogenic microbes [54]. Accomplished by members of the domain Archaea, methanogenesis involves the anaerobic conversion of decaying organic matter to yield $\mathrm{CO}_{2}$ and $\mathrm{CH}_{3}$ [54]. $\mathrm{CO}_{2}$ production potentially causes the local precipitation of calcium carbonate.

Although zonation is a common feature of fossiliferous concretions at Vancouver Island sites, some specimens occur as nuclei in concretions that have homogeneous form. The external shape is commonly determined by the internal fossil (Figure 12). 


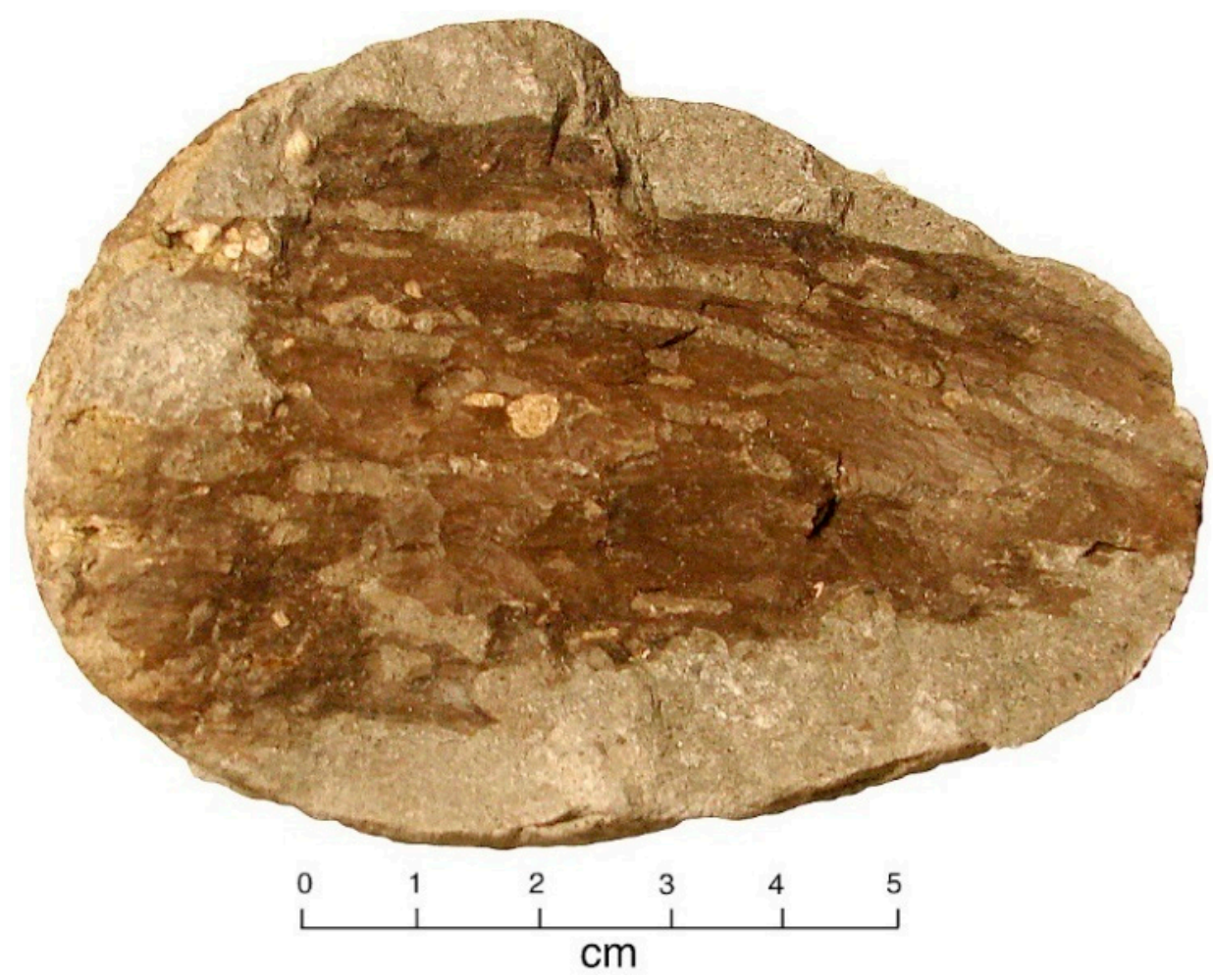

Figure 12. Longitudinal view of fossil wood in an unzoned concretion, Shelter Point.

\section{Conclusions}

Vancouver Island sedimentary rocks provide a rare opportunity to study fossil wood that was preserved in shallow marine basin environments that range in age from Lower Cretaceous to Paleocene. These fossil woods are of particular scientific interest because they are mineralized with calcite. They are commonly found in strata that contain abundant invertebrate fossils that can be used to determine geologic age based on biostratigraphy. Plant and animal fossils are preserved within calcareous concretions in detrital siliceous sediments, suggesting that the precipitation of calcite cement was triggered by substances released during the degradation of organic matter. The excellent anatomical detail in most specimens is a result of several factors: the mild geochemical conditions that favor calcite precipitation, and a rate concretion formation that allowed wood that exceeded the rate of tissue degradation. The time required for growth of carbonate concretions is variable, with rates that are determined by porewater flow rates and $\mathrm{CaCO}_{3}$ supersaturation. Mathematical calculations show that for a typical slowly flowing porewater supersaturated in $\mathrm{CaCO}^{3}$ by $10 \mathrm{ppm}$, concretions of $1 \mathrm{~cm}$ diameter can develop in $\approx 500$ years [55]. A much longer time would be required to produce the final mass, but the early stages of calcite precipitation may have been sufficient to permineralize wood that forms the concretion nucleus.

Author Contributions: G.E.M. made petrographic thin sections, obtained optical and scanning electron photomicrographs, and wrote manuscript first draft. G.B. was responsible for field work, provided many of the study specimens, and prepared acetate peels. Both authors contributed to writing and editing of the final manuscript. All authors have read and agreed to the published version of the manuscript.

Funding: The authors declare no specific funding for this project.

Data Availability Statement: Specimens used in this study are archived in G.M.'s research collection at the Western Washington University Geology Department; they are available for study by other researchers pending the end of the current Covid 19 pandemic restrictions. 
Acknowledgments: The authors thank Vancouver Island collectors Gerald Cranham, Joe Morin and Rick Ross for their donation of specimen. Jim Haggart, Canada Geological Survey, provided helpful information regarding the biostratigraphy of Cretaceous and Eocene formations. Rick Ross and Mike Viney provided suggestions for the improving the manuscript first draft.

Conflicts of Interest: The authors declare no competing interests.

\section{References}

1. Mindell, R.A.; Stockey, R.A.; Beard, G. Permineralized Fagus nuts from the Eocene of Vancouver Island, Canada. Int. J. Plant Sci. 2009, 170, 551-560. [CrossRef]

2. Atkinson, B.A.; Stockey, R.A.; Rothwell, G.W. The early phylogenetic diversification of Cornales: Permineralized cornalean fruits from the Campanian (upper Cretaceous) of western North America. Int. J. Plant Sci. 2017, 178, 556-566. [CrossRef]

3. Stockey, R.A.; Rothwell, G.W.; Atkinson, B. Late Cretaceous diversification of cupressaceous conifers: A taiwanoid seed cone from the Eden Main, Vancouver Island, British Columbia, Canada. Int. J. Plant Sci. 2020, 181, 529-541. [CrossRef]

4. Jud, N.A.; Wheeler, E.A.; Rothwell, G.W.; Stockey, R.A. Angiosperm wood from the upper Cretaceous (Coniacian) of British Columbia. IAWA J. 2017, 38, 141-161. [CrossRef]

5. Brink, K.S.; Stockey, R.A.; Beard, G.; Wehr, W.C. Cunninghamia hornbeyensis sp. nov.: Permineralized twigs and leaves from the upper Cretaceous of Hornby Island, British Columbia, Canada. Rev. Paleobotany Palynol. 2009, 155, 89-98. [CrossRef]

6. Ludvigsen, R.; Beard, G. West Coast Fossils. A Guide to Ancient Life of Vancouver Island; Whitecap Books: Vancouver, BC, Canada, 1994.

7. Siurek, J.; Chevalier, P.; Ro, C.; Chun, H.Y.; Zieba, E.; Kuczomow, A. Studies on the wood tissue substitution by silica and calcite during preservation of fossil wood. J. Alloys Compd. 2004, 36, 107-115. [CrossRef]

8. Buurman, P. Mineralization of fossil wood. Scr. Geol. 1972, 12, 1-43.

9. Sweeney, I.J.; Chin, K.; Hower, J.C.; Budd, D.; Wolfe, D.G. Fossil wood from the middle Cretaceous Moreno Hill Formation: Unique expressions of wood mineralization and implications for the processes of wood preservation. Int. J. Coal Geol. 2009, 79, 1-17. [CrossRef]

10. Greenland, C.W. The replacement of wood by calcite. Econ. Geol. 1918, 13, 116-119. [CrossRef]

11. Galwitz, H. Verkalung und Verskisalung von Hölzern in der Braunkohle des Geiseltale. Wissenschaftliche Zeitschrift der MartinLuther-Universität Halle- Wittenberg Mathematische-Naturwissenschaftliche Reihe 1954, 4, 41-44.

12. Francis, J.E. A 50-million-year-old fossil forest from Strathcona Fiord, Ellesmere Island, Arctic Canada: Evidence for a warm polar climate. Arctic 1988, 41, 314-318. [CrossRef]

13. Boyce, C.K.; Hazen, R.M.; Knoll, A.H. Nondestructive, in situ, cellular-scale mapping of elemental abundances in permineralized fossils. Proc. Natl. Acad. Sci. USA 2001, 9, 5970-5974. [CrossRef] [PubMed]

14. Mustoe, G.E. Wood petrifaction: A new view of permineralization and replacement. Geosciences 2017, 17, 119. [CrossRef]

15. Scott, A.C.; Collinson, M.E. Non-destructive multiple approaches to interpret the preservation of plant fossils: Implications for calcium-rich permineralizations. J. Geol. Soc. Lond. 2003, 160, 857-862. [CrossRef]

16. Higgins, C.G. Calcification of some California Cretaceous wood. Geol. Soc. Am. Bull. 1960, 71, 1887-1888.

17. Higgins, C.G. Significance of some fossil wood from California. Science 1961, 134, 473-479. [CrossRef]

18. Brand, L.S. Calcified wood found in Pleistocene sand. Ohio Acad. Sci. Proc. 1930, 8, 409.

19. Brand, L.S. Calcified wood in upland sand near Cincinnati, Ohio. Ohio J. Sci. 1932, 32, 55-62.

20. Lorenz, V.J.; Rößler, R.; Schmidt, R.T. Fossiles Holz aus Fluorapatit und Calcit von der Tjornes-Halbinsel, Nord-Island. Der Aufschluss 2010, 61, 17-25.

21. Lange, P.; Steiner, W. Rasterelektronenmikroskopichse Untersuchung an verkalyten Holzeresten aus dem pleitozanen Travertin von Weimar. Quartaenaepaleontologie 1984, 5, 225-236.

22. Muller, J.E.; Jeletsky, J.A. Geology of the Upper Cretaceous Nanaimo Group, Vancouver Island and Gulf Islands, British Columbia. Geol. Surv. Canada, Paper 1970, 69, 1-77.

23. Mustard, P.S. The Upper Cretaceous Nanaimo Group, Georgia Basin. In Geology and Geologic Hazards of the Vancouver Region, Southwestern British Columbia; Monger, J.H.W., Ed.; Bulletin 481; Geological Survey of Canada: Ottawa, ON, Canada, 1994; pp. 27-95.

24. Kent, B.A.P.; Dashtgard, S.E.; Huang, C.; MacEachern, J.A.; Gibson, H.D.; Cathyl-Huhn, G. Initiation and early evolution of a forearc basin: Georgia Basin, Canada. Basin Res. 2020, 32, 163-185. [CrossRef]

25. Irving, E. Whence British Columbia? Nature 1985, 314, 673-674. [CrossRef]

26. Ward, P.D.; Hurtado, J.M.; Kirschvink, J.L.; Verosub, K.L. Measurements of the Cretaceous paleolatitude of Vancouver Island: Consistent with the Baja-British Columbia hypothesis. Science 1997, 277, 1642-1645. [CrossRef]

27. Housen, B.A.; Beck, M.E. Testing terrane transport: An inclusive approach to the Baja B.C. controversy. Geology 1979, 27, 1143-1146. [CrossRef]

28. Keppie, F.; Dostal, J. Evaluation of the Baja controversy using paleomagnetic and faunal data, plume magmatism, and piercing points. Tectonophysics 2001, 339, 427-442. [CrossRef]

29. Butler, R.F.; Gehrels, G.E.; Kodama, K.P. Baja British Columbia hypothesis. GSA Today 2001, 11, 4-10. [CrossRef] 
30. Kim, B.Y.; Kodma, K.P. A compaction correction for the paleomagnetism of the Nanaimo Group sedimentary rocks: Implications for the Baja British Columbia hypothesis. J. Geophys. Res. 2004, 109, 1-17. [CrossRef]

31. Bell, W.A. Flora of the Upper Cretaceous Nanaimo Group of Vancouver Island, British Columbia; Memoir 293; Geological Survey of Canada: Ottawa, ON, Canada, 1956; 84p.

32. Haggart, J.W. Latest Jurassic and Cretaceous paleogeography of the Northern Insular Belt, British Columbia. In Mesozoic Paleogeography of the Western United States II; Pacific Coast Paleogeography Symposium 2, Special Volume 71; Dunne, G., McDougal, K.A., Eds.; Pacific Section Society of Economic Paleontologists and Mineralogists: Los Angeles, CA, USA, 1993; pp. 463-475.

33. Nicholls, E.L.; Meckert, D. Marine reptiles from the Nanaimo Group (Upper Cretaceous) of Vancouver Island. Can. J. Earth Sci. 2002, 39, 1591-1603. [CrossRef]

34. Barghoorn, E.S. Degradation of plant fossils in organic sediments. J. Sediment. Petrol. 1952, 22, 34-41.

35. Kirk, T.K.; Cowling, E.B. Biological decomposition of solid wood. In The Chemistry of Solid Wood; Rowell, E.B., Ed.; Advances in Chemistry Series 207; American Chemical Society: Washington, DC, USA, 1984; pp. 455-487.

36. Treu, A.; Zimmer, K.; Brischke, C.; Laney, E.; Gobakken, L.R.; Aloui, F.; Cragg, S.M.; Flæte, P.O.; Humar, M.; Westin, M.; et al. Timber in marine environments. BioResources 2019, 4, 10161-10184.

37. Christensen, M.; Frosch, M.; Jensen, P.; Schnell, U.; Shashoua, Y.; Nielsen, O.F. Waterlogged archaeological wood—Chemical changes by conservation and degradation. J. Raman Spectrosc. 2006, 37, 1171-1178. [CrossRef]

38. Mustoe, G.E. Mineralogy of non-silicified fossil wood. Geosciences 2018, 8, 85. [CrossRef]

39. Luczaj, J.A.; Leavitt, S.W.; Csank, A.Z.; Panyuskina, I.P.; Wright, W.E. Comment on “Nonmineralized fossil wood" by George, E. Mustoe (Geosciences, 2018). Geosciences 2018, 6, 1-7.

40. Zeebe, R.E.; Wolf-Gladrow, D. $\mathrm{CO}_{2}$ in Sea Water; Elsevier: Amsterdam, The Netherlands, 2001.

41. Kump, L.R.; Bralower, T.J. Ocean acidification in deep time. Oceanography 2009, 22, 94-107. [CrossRef]

42. Gazeau, F.; Parker, L.M.; Comeau, S.; Gattuso, J.; O'Conner, H.; Martin, S.; Pörtner, H.; Ross, P. Impact of ocean acidification on marine shelled molluscs. Mar. Biol. 2013, 160, 2207-2245. [CrossRef]

43. Leo, R.F.; Barghoorn, E.S. Silicification of Wood. Bot. Mus. Leafl. Harv. Univ. 1976, 25, 1-46.

44. Mustoe, G.E. Late Tertiary petrified wood from Nevada, USA: Evidence of multiple silicification pathways. Geosciences 2015, 5, 286-309. [CrossRef]

45. Mustoe, G.E. Density and loss on ignition as indicators of fossilization of silicified wood. IAWA J. 2016, 37, 98-111. [CrossRef]

46. Mustoe, G.E.; Acosta, M. Origin of petrified wood color. Geosciences 2016, 6, 25. [CrossRef]

47. McBride, E.F.; Picard, M.D.; Milliken, K. Calcite-cemented concretions in Cretaceous sandstone, Wyoming and Utah, USA. J. Sediment. Res. 2003, 73, 462-483. [CrossRef]

48. Morita, R.Y. Calcite precipitation by marine bacteria. Geomicrobiol. J. 1980, 2, 63-82. [CrossRef]

49. Dickson, J.A.D.; Barber, C. Petrography, chemistry, and origin of early diagentic concretions in the Lower Carboniferous of the Isle of Man. Sedimentology 1976, 23, 147-283. [CrossRef]

50. Pratt, B.R. Septarian concretions: Internal cracking caused by synsedimentary earthquakes. Sedimentology 2001, 489, 189-213. [CrossRef]

51. Raiswell, R.; Fisher, Q. Mudrock-hosted carbonate concretions: A review of growth mechanisms and their influence on chemical and isotopic composition. J. Geol. Soc. 1999, 157, 239-251. [CrossRef]

52. Popa, R.; Kinkle, B.K.; Badescu, A. Pyrite framboids as biomarkers for iron-sulfur systems. Geomicrobiol. J. 2004, 21, 193-206. [CrossRef]

53. Mozley, P.S.; Davis, J.M. Internal structure and mode of growth of elongate calcite concretions: Evidence for small-scale chemical heterogeneity in groundwater. Geol. Soc. Am. Bull. 2005, 117, 1400-1412. [CrossRef]

54. Thauer, R.K. Biochemistry of methanogenesis: A tribute to Marjory Stephenson. Microbiology 1998, 144, 2377-2406. [CrossRef]

55. Berner, R.A. Rate of concretion growth. Geochim. Cosmochim. Acta 1968, 32, 447-483. [CrossRef] 